Jan KOROŃSKI

Instytut Matematyki Politechniki Krakowskiej

jkorons@pk.edu.pl

\title{
ZARYS DZIEJÓW MATEMATYKI W SIEDEMDZIESIECIOLECIU POLITECHNIKI KRAKOWSKIEJ
}

\begin{abstract}
Streszczenie
Przedmiotem pracy jest historia matematyki w Politechnice Krakowskiej w latach 1945-2015. Zaprezentowano sylwetki wybranych wybitnych matematyków w historii Politechniki Krakowskiej (Mirosław Krzyżański, Jan Bochenek, Feliks Barański oraz Irena Łojczyk-Królikiewicz) i podstawowe informacje o ich osiągnięciach naukowych.

Słowa kluczowe: Politechnika Krakowska, Instytut Matematyki PK, historia matematyki

\section{Wstęp}

W 2015 roku Politechnika Krakowska obchodziła jubileusz siedemdziesięciolecia swojej działalności naukowo-dydaktycznej. ${ }^{1}$ Bez matematyki nie ma politechniki, stąd też w powstającej po II wojnie światowej uczelni od razu zatrudniono matematyków. W ten sposób Politechnika Krakowska stała się jednym z liczących się ośrodków matematycznych w Krakowie obok Uniwersytetu Jagiellońskiego, Akademii Górniczej (od 1949 roku Akademii Górniczo-Hutniczej), Akademii Rolniczej (obecnie Uniwersytetu Rolniczego) i Wyższej Szkoły Pedagogicznej (obecnie Uniwersytetu Pedagogicznego) oraz Akademii Ekonomicznej (obecnie Uniwersytetu Ekonomicznego).

Powstała ona z Wydziałów Politechnicznych Akademii Górniczej. Wydziały te - Wydział Architektury, Wydział Inżynierii i Wydział Komunikacji - od początku posiadały pełną autonomię, wyrażającą się oddzielnym zarządzaniem i administracją, osobnym budżetem oraz senatem, którego przewodniczącym był odrębny prorektor. W roku 1954
\end{abstract}

1 O historii Politechniki Krakowskiej zob.: Flaga (red.) 2005; Muszyński (red.) 1995; Rączka 1976 oraz Wątorski (red.) 1970. 
zostały one przekształcone w samodzielną uczelnię nazwaną Politechniką Krakowską, a jako datę jej założenia przyjęto 1 lipca 1945 roku. $^{2}$

Obecnie w Krakowie matematykę można studiować na czterech uczelniach, mianowicie: w Uniwersytecie Jagiellońskim, Uniwersytecie Pedagogicznym, Akademii Górniczo-Hutniczej i Politechnice Krakowskiej. W tym opracowaniu przedstawiamy zarys dziejów matematyki w ostatniej z wymienionych.

Oprócz nich w Krakowie po wojnie (od 20 listopada 1948 roku) działał Państwowy Instytut Matematyczny, który w 1952 roku został włączony do Polskiej Akademii Nauk i od tego czasu nosi nazwę Instytutu Matematycznego Polskiej Akademii Nauk³. Obok środowiska matematycznego skupionego w UJ odgrywał on wiodącą rolę w badaniach naukowych w różnych dziedzinach matematycznych. $Z$ instytutem tym za sprawą prof. Mirosława Krzyżańskiego ściśle współpracowali matematycy z Politechniki Krakowskiej.

\section{Początki matematyki w Politechnice Krakowskiej - Wydziały Politechniczne Akademii Górniczej}

Dzieje matematyki w Politechnice Krakowskiej związane są ze znakomitymi postaciami polskich naukowców. Do grona najwybitniejszych z nich należy bez wątpienia zaliczyć profesora Mirosława Krzyżańskiego (1907-1965), który po II wojnie światowej, w 1945 roku, w ramach tzw. repatriacji z ZSSR, tak jak wielu rodaków, został zmuszony do opuszczenia Wileńszczyzny i przybył do Krakowa. W początkowym okresie formowania się matematyki w Politechnice Krakowskiej wywarł największy wpływ na jej kierunek badań naukowych i metody dydaktyczne w zakresie matematyki na wiele dziesięcioleci. Prześledzimy tutaj powojenne losy profesora Krzyżańskiego nieco bardziej szczegółowo, gdyż splatają się one ściśle z historią matematyki w Politechnice Krakowskiej. Oddziaływanie profesora sięga nawet czasów współczesnych. Dzieje się to za sprawą pracowników naukowych Instytutu Matematyki PK, którzy w wielu przypadkach nadal kontynuują i rozwijają kierunki badawcze zainicjowane przez Krzyżańskiego tuż po II wojnie świato$\mathrm{wej}^{4}$, w czasie gdy dopiero organizowano pracę politechniki.

Mirosław Krzyżański 1 lipca 1945 roku został zatrudniony na stanowisku starszego asystenta w Politechnice Śląskiej z siedzibą w Krakowie. ${ }^{5}$ Następnie po przeniesieniu we wrześniu Politechniki Śląskiej do Gliwic z dniem 1 listopada 1945 roku otrzymał stanowisko adiunkta na Wydziałach Politechnicznych Akademii Górniczej, czyli w Politechnice Krakowskiej.

Formalnie Wydziały Politechniczne AG otrzymały swoje nazwy: Wydział Architektury, Wydział Inżynierii i Wydział Komunikacji na mocy dekretu z dn. 03.02.1947 roku,

\footnotetext{
2 Muszyński (red.) 1995.

3 Instytut Matematyczny Polskiej Akademii Nauk 2015.

${ }^{4}$ Masiarz (red.) 1995 (o Instytucie Matematyki na ss. 31-63).

${ }^{5}$ Archiwum Politechniki Krakowskiej (dalej cyt. APK), Teczka osobowa Mirosława Krzyżańskiego.
} 
obowiązującego od 01.04.1945 roku. W jego następstwie minister oświaty powołał na tych wydziałach 16 katedr, w tym trzy matematyczne. ${ }^{6} \mathrm{Na}$ Wydziale Inżynierii katedra matematyczna kierowana była początkowo przez prof. dr Władysława Nikliborca (1899-1948). Wcześniej, przez jeden semestr w roku akademickim 1945/1946, kierował nią prof. Franciszek Leja (1885-1979). Natomiast dwie katedry matematyczne, powstałe na Wydziale Komunikacji, objęli wówczas: dr Adam Bielecki z UJ, pracujący na Wydziale Komunikacji na stanowisku zastępcy profesora do końca 1947 roku (do końca września 1947 roku kierował on również Katedrą Matematyki na Wydziale Inżynierii zastępując tam Nikliborca) oraz kontraktowy profesor nadzwyczajny dr Otto Nikodym (1889-1974), który po połączeniu obu tych katedr w jedną kierował Katedrą Matematyki do końca 1946 roku. Po opuszczeniu Krakowa przez profesora Nikliborca w 1947 roku kierownictwo połączonej Katedry Matematyki na Wydziale Komunikacji objął jej adiunkt - dr Mirosław Krzyżański. W październiku 1947 roku kierownikiem Katedry Matematyki na Wydziale Inżynierii został dr Jacek Szarski (1921-1980), docent UJ, pracujący na stanowisku zastępcy profesora. Po przejściu Szarskiego na UJ do sierpnia 1951 roku zarządzanie Katedrą Matematyki na Wydziale Inżynierii powierzono prof. dr. Antoniemu Plamitzerowi (1889-1954), który kierował równocześnie Katedrą Geometrii Wykreślnej. Od września 1951 roku do czerwca 1953 roku kierownikiem Katedry Matematyki na Wydziale Inżynierii był jej adiunkt, mgr Zdzisław Siedmiograj (1906-1962).

Na stanowisku adiunkta Mirosław Krzyżański pracował do 1 lutego 1948 roku. W tymże roku na Uniwersytecie Jagiellońskim został przeprowadzony jego przewód habilitacyjny na podstawie rozprawy ${ }^{7}$ pt. „Sur le problème de Dirichlet pour l’équation linéaire du type elliptique dans un domaine non borné" (Rendiconti dell'Accademia Nazionale dei Lincei, Classe di Scienze Fisiche, Matematiche e Naturali 4 (1948), ss. 408-416). Od 1 lutego do 1 lipca 1949 roku Krzyżański pracował na stanowisku zastępcy profesora. W dniu 1 lipca 1949 roku został mianowany profesorem nadzwyczajnym Wydziałów Politechnicznych AGH, przekształconych później w Politechnikę Krakowską. Oprócz pracy w politechnice, gdzie w Katedrze Matematyki prowadził słynne seminarium z równań cząstkowych, od roku 1949 Krzyżański prowadził również seminaria i wykład nt. Wybrane zagadnienia z zakresu równań różniczkowych o pochodnych cząstkowych w Państwowym Instytucie Matematycznym (od 1952 roku w Instytucie Matematycznym PAN). Od 1 września 1952 do 28 lutego 1953 miał również wykład zlecony nt. Elementy rachunku prawdopodobieństwa i statystyki matematycznej na Wydziale Matematyczno-Fizyczno-Chemicznym Uniwersytetu Jagiellońskiego, a w latach 1953-1954 również wykład specjalny nt. Równania o pochodnych czastkowych w Uniwersytecie Warszawskim. ${ }^{8}$

Po ukazaniu się Zarządzenia Ministra Szkolnictwa Wyższego z dnia 21.08.1953 r. z mocą od dn. 31.07.1953 r. na Wydziałach Politechnicznych powołano do istnienia:

${ }^{6}$ Masiarz (red.) 1995, ss. 32-33.

7 Archiwum Uniwersytetu Jagiellońskiego (dalej cyt. AUJ), Krzyżański Mirosław (teczka habilitacyjna) sygn. WMP 46.

${ }^{8}$ Koroński 2013. 
Wydział Architektury, Wydział Budownictwa Lądowego, Wydział Budownictwa Wodnego i Wydział Mechaniczny. Jednocześnie zlikwidowano Katedry Matematyki na Wydziałach Komunikacji i Inżynierii i utworzono jedną Katedrę Matematyki na Wydziale Budownictwa Lądowego pod kierownictwem profesora Mirosława Krzyżańskiego. W jej skład wchodziły: Zakład Matematyki Ogólnej, którego kierownikiem został zastępca profesora mgr Z. Siedmiograj, i Zakład Analizy Matematycznej, kierowany przez profesora Krzyżańskiego. ${ }^{9}$

\section{Formalne powołanie do istnienia Politechniki Krakowskiej}

\subsection{Rola Mirosława Krzyżańskiego}

w rozwoju matematyki w początkowym okresie istnienia politechniki

W dniu 7 lipca 1954 roku Uchwałą Rady Ministrów została formalnie powołana do istnienia Politechnika Krakowska z datą założenia 1 lipca 1945 roku. ${ }^{10}$ Wówczas to Mirosław Krzyżański został mianowany profesorem zwyczajnym Katedry Matematyki Wydziału Budownictwa Lądowego Politechniki Krakowskiej. Pełnił jednocześnie funkcję kierownika międzywydziałowej Katedry Matematyki PK.

Od 1 października 1955 roku decyzją ministra został przeniesiony na stanowisko profesora nadzwyczajnego przy Katedrze Funkcji Analitycznych Uniwersytetu Jagiellońskiego. ${ }^{11}$ W politechnice wypromował trzech doktorów (Jana Burzyńskiego - 1955, Genowefę Majcher - 1956 i Zdzisława Siedmiograja - 1959). Profesorem zwyczajnym UJ został 12 stycznia 1961 roku, a 1 września 1963 roku, po przejściu prof. Franciszka Leji na emeryturę, objął kierownictwo Katedry Funkcji Analitycznych UJ. Krzyżański miał ogromne zasługi w kształceniu kadr naukowych. Prowadził seminarium w ramach Katedry Funkcji Analitycznych UJ i seminarium w Instytucie Matematycznym PAN. Był promotorem w dziesięciu przewodach doktorskich. W UJ wypromował formalnie sześć, a w zasadzie siedem osób. Byli to: Irena Łojczyk-Królikiewicz - 1960, Piotr Besala -1961, Zdzisław Frydrych -1961, Bogdan Choczewski - 1962, Eugeniusz Śliwiński - 1963, Alina Dawidowiczowa - 1965 i Marian Łuczyński, którego egzamin doktorski odbył się w czerwcu 1965 roku, a obrona pracy doktorskiej miała miejsce w 1966 roku już po śmierci Krzyżańskiego. Formalnym promotorem M. Łuczyńskiego został wtedy prof. Jacek Szarski. W UJ Mirosław Krzyżański pełnił funkcję prodziekana w latach 1958/1959 i 1959/1960, a w latach 1959/1960 i 1960/1961 był również prezesem Oddziału Krakowskiego Polskiego Towarzystwa Matematycznego. ${ }^{12}$

Krzyżański wielokrotnie wyjeżdżał za granicę, utrzymując żywe kontakty naukowe ze znaczącymi matematykami. Prezentował swoje wyniki we Włoszech, Rumunii, Czechosłowacji i na Węgrzech, gdzie był zapraszany na wykłady i konferencje. Opublikował

\footnotetext{
9 APK Mirosław Krzyżański (teczka osobowa) sygn. 98/388.

${ }_{10}$ Muszyński (red.) 1995, s. 25.

11 AUJ Krzyżański Mirosław (teczka profesorska) sygn. MFC 34.

12 Koroński 2013, ss. 12-13.
} 
41 prac naukowych i obszerną dwutomową monografię $\mathrm{w}$ języku angielskim $\mathrm{z}$ równań różniczkowych cząstkowych rzędu drugiego (1971), poprzedzoną wydaniem wersji polskojęzycznej (1957 i 1962) oraz jeszcze wcześniej wydaniem dwutomowego skryptu na ten temat (1951 i 1952). Monografia Krzyżańskiego w języku angielskim ukazała się sześć lat po śmierci autora, jednak zdążył on jeszcze przygotować jej tekst do druku. Ponadto w latach 1948 i 1950 nakładem Koła Mechaników Wydziału Komunikacji Akademii Górniczej w Krakowie wydrukowano trzy skrypty - stenogramy wykładów Krzyżańskiego z geometrii analitycznej i rachunku różniczkowego funkcji jednej zmiennej.

Pomimo przejścia do Uniwersytetu Jagiellońskiego profesor Krzyżański kontynuował kontakty naukowe ze środowiskiem politechnicznym.

Mirosław Krzyżański zmarł nagle na atak serca w dniu 1 grudnia 1965 roku w wieku 58 lat. Został pochowany na Cmentarzu Rakowickim w Krakowie.

\subsection{Ogólna charakterystyka osiągnięć naukowych prof. Mirosława Krzyżańskiego}
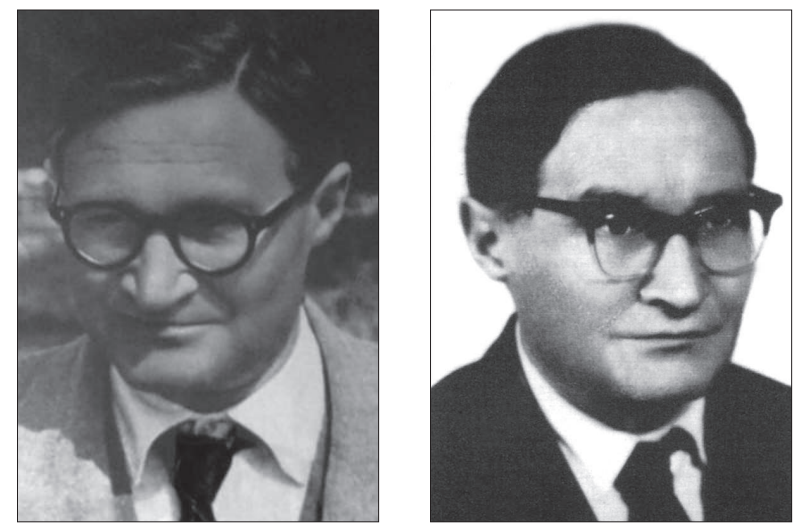

Mirosław Krzyżański (1907-1965)

W początkowym okresie działalności naukowej badania naukowe Krzyżańskiego skupiały się na tematyce wchodzącej w zakres teorii funkcji rzeczywistych. Z tej dziedziny w roku 1934 uzyskał doktorat w Uniwersytecie Wileńskim na podstawie pracy „O uogólnionych funkcjach bezwzględnie ciągłych dwóch zmiennych”, w której zajął się uogólnieniem pojęcia całki Denjoy na funkcje dwóch zmiennych. Zagadnienie to kontynuował w kolejnych dwóch publikacjach.

Jeszcze przed drugą wojną światową, będąc na stypendium Funduszu Kultury Narodowej we Lwowie, zajmował się Krzyżański równaniami różniczkowymi cząstkowymi typu hiperbolicznego rzędu drugiego. Nawiązał tam współpracę naukową z Juliuszem Schauderem. W pierwszej swojej pracy z równań różniczkowych cząstkowych („Sur les évaluations pour une équation du type hyperbolique", Studia Mathematica 5(1935), ss. 151-154) uzyskał oszacowania typu Friedrichsa i Lévy’ego dla rozwiązania równania liniowego hiperbolicznego rzędu drugiego. W kolejnej publikacji („Quasilineare 
Differentialgleichungen zweiter Ordnung vom hyperbolischen Typus. Gemischte Randwertaufgaben", Studia Mathematica 6 (1936), 162-189), wspólnie z Schauderem, przy wykorzystaniu oszacowań uzyskanych przez Krzyżańskiego i poprzez zastosowanie twierdzenia Schaudera o punkcie stałym, obydwaj matematycy wykazali istnienie rozwiązania problemu mieszanego dla quasi-liniowego równania hiperbolicznego o współczynnikach nieanalitycznych.

Dziedziną, w której Mirosław Krzyżański miał największe osiągnięcia, są równania różniczkowe cząstkowe typu parabolicznego i eliptycznego. Zajmował się nimi głównie po drugiej wojnie światowej w Krakowie. Skoncentrował się wówczas na następujących grupach zagadnień:

1) jednoznaczność, istnienie i zasada ekstremum rozwiązań problemów granicznych dla równań cząstkowych typu eliptycznego i parabolicznego,

2) zagadnienia związane $z$ rozwiązaniem podstawowym dla równania cząstkowego typu parabolicznego,

3) zagadnienia związane z asymptotycznym zachowaniem się rozwiązań równania parabolicznego przy zmiennej czasowej zmierzającej do nieskończoności,

4) równania różniczkowe i różniczkowo-całkowe w kontekście rachunku prawdopodobieństwa.

W każdym z wyżej wymienionych tematów Krzyżański miał pokaźny i istotny wkład, a w wielu wypadkach wyniki jego pracy weszły na stałe do literatury światowej. ${ }^{13}$

\subsection{Działalność naukowa i organizacyjna Katedry Matematyki po przejściu prof. Mirosława Krzyżańskiego na Uniwersytet Jagielloński}

Po przejściu profesora Krzyżańskiego na uniwersytet w 1955 roku kierownikiem Katedry Matematyki w Politechnice Krakowskiej zostaje jego zastępca, Zdzisław Siedmiograj. Po śmierci Siedmiograja, na początku 1962 roku stanowisko to obejmuje prof. dr inż. Aleksander Lisowski (1919-1976) i piastuje tę funkcję do roku 1964. Następnie kierowanie katedrą przejmuje doc. dr inż. Janusz Murzewski (ur. 1928). W październiku 1958 roku zarządzeniem Ministerstwa Szkolnictwa Wyższego wprowadzono zmiany w strukturze zakładów. Zakład Matematyki Ogólnej przemianowano na Zakład Matematyki I, a Zakład Analizy Matematycznej na Zakład Matematyki II.

Istotnymi wydarzeniami, mającymi wpływ na historię matematyki w Politechnice Krakowskiej, było uzyskanie w latach sześćdziesiątych habilitacji przez kilkoro matematyków pracujących w tej uczelni. Mianowicie 7 maja 1963 roku habilitację w Uniwersytecie im. A. Mickiewicza w Poznaniu uzyskał dr Feliks Barański. Dnia 20 kwietnia 1966 roku na Wydziale Inżynierii Budowlanej Politechniki Warszawskiej habilitowała się dr Genowefa Majcher, a 4 marca 1968 roku w Instytucie Matematyki Politechniki Warszawskiej - Irena Łojczyk-Królikiewicz. Na Wydziale Matematyczno-Fizyczno-Chemicznym Uniwersytetu Jagiellońskiego 19 czerwca 1969 roku habilitację uzyskał dr Jan Bochenek. Wszyscy z wy-

13 Więcej informacji na temat postaci i rezultatów naukowych M. Krzyżańskiego można znaleźć w pracy Koroński 2013. 
żej wymienionych odegrali istotną rolę i wypełniali bardzo ważne funkcje w utworzonym niebawem Instytucie Matematyki Politechniki Krakowskiej, wywierając zasadniczy wpływ na rozwój kadr naukowych i dydaktycznych uczelni w dziedzinie matematyki ${ }^{14}$.

\section{Matematyka w Politechnice Krakowskiej w strukturze instytutu międzywydziałowego}

\subsection{Instytut Matematyki Politechniki Krakowskiej w latach 1970-1999}

W kwietniu 1970 roku w wyniku zarządzenia Ministerstwa Oświaty i Szkolnictwa Wyższego w uczelni nastąpiła likwidacja katedr i od września wprowadzono strukturę instytutową. Połączono Katedrę Matematyki i Katedrę Geometrii Wykreślnej w Instytut Matematyki Politechniki Krakowskiej. W lutym 1992 roku nastąpiło wydzielenie się z Instytutu Zakładu Geometrii Wykreślnej, który następnie przekształcił się w Samodzielny Zakład Geometrii Wykreślnej i Grafiki Inżynierskiej i został umiejscowiony w strukturze Wydziału Architektury. ${ }^{15}$

Pierwszym dyrektorem Instytutu Matematyki Politechniki Krakowskiej został doc. dr hab. Jan Bochenek (1927-2009), a jego zastępcą doc. dr hab. inż. arch. Zbigniew Pałasiński (1921-1991). Wyodrębniono wówczas cztery zespoły naukowe i ich kierowników, a mianowicie: Równań Różniczkowych kierowany przez doc. dra hab. Feliksa Barańskiego (1915-2006), Metod Numerycznych - doc. dra hab. Jana Bochenka, Równań Funkcyjnych - doc. dr hab. Genowefę Majcher i Zastosowań Metod Geometrycznych w Technice kierowany przez doc. dra inż. Karola Biedę. ${ }^{16}$ Taka struktura instytutu istniała do 31 stycznia 1974 roku.

Druga kadencja nie przyniosła zmiany na stanowisku dyrektora Instytutu Matematyki. Nadal funkcję tę piastował prof. dr hab. Jan Bochenek (profesor nadzwyczajny - 1977, zwyczajny - 1990). Zastępcami dyrektora zostali prof. dr hab. Feliks Barański (nominację na profesora nadzwyczajnego otrzymał w październiku 1972 roku) i doc. dr inż. Stanisław Świsterski. W lutym 1974 roku nastąpił podział Instytutu Matematyki PK na cztery jednostki: Zakład Metod Numerycznych (kierownik doc. dr hab. Jan Bochenek), Zakład Równań Różniczkowych Fizyki i Techniki (prof. dr. hab. Feliks Barański), Zakład Podstaw Analizy Matematycznej (doc. dr hab. Genowefa Majcher) i Zakład Geometrii Wykreślnej (doc. dr hab. Karol Bieda). Po przejściu Biedy na emeryturę w 1975 roku kierownikiem zakładu został prof. dr hab. inż. arch. Zbigniew Pałasiński, który tytuł profesora nadzwyczajnego uzyskał w 1974 roku. Taka struktura trwała do sierpnia 1979 roku.

Od września 1976 roku funkcję dyrektora Instytutu objął doc. dr inż. Stanisław Świsterski, a zastępcami zostali prof. dr hab. Feliks Barański i dr Jan Luchter. W marcu 1978 roku utworzono również nowe stanowisko zastępcy dyrektora ds. administracyjnych, które objęła inż. Maria Tutajewska (zlikwidowano je w październiku 1993 roku).

\footnotetext{
${ }^{14}$ Masiarz (red.) 1995, ss. 40-44.

15 Muszyński (red.) 1995, ss. 315-316.

${ }_{16}$ Masiarz (red.), ss. 40-41.
} 
We wrześniu 1979 roku dyrektorem Instytutu Matematyki Politechniki Krakowskiej na kolejne dwie kadencje (do końca sierpnia 1985 roku) został prof. dr hab. Feliks Barański ${ }^{17}$. Osiągnąwszy wiek emerytalny z końcem drugiej kadencji, nie zaprzestał jednak swojej działalności w Instytucie. Zatrudnienie profesora Barańskiego na części etatu trwało do września 1991 roku, a niemal do samej śmierci (w lutym 2006 roku) prowadził seminarium naukowe $\mathrm{z}$ równań różniczkowych cząstkowych. Zastępcami dyrektora w pierwszej kadencji zostali: doc. dr inż. Stanisław Świsterski do czerwca 1980 roku, czyli do osiągnięcia wieku emerytalnego, prof. dr hab. inż. arch. Zbigniew Pałasiński od lipca 1980 roku i dr Jan Luchter.

Od września 1979 roku Instytut składał się z trzech zakładów: Zakładu Analizy Matematycznej, pod kierownictwem prof. dr hab. Feliksa Barańskiego, Zakładu Równań Różniczkowych i Analizy Funkcjonalnej, pod kierownictwem prof. dra hab. Jana Bochenka i Zakładu Geometrii Wykreślnej kierowanego przez prof. dra hab. inż. arch. Zbigniewa Pałasińskiego. W drugiej kadencji zastępcą dyrektora był dr Jan Milewski.

Od września 1985 roku dyrektorem Instytutu Matematyki został prof. dr hab. inż. arch. Zbigniew Pałasiński. Funkcję tę piastował do swojej śmierci w lutym 1991 roku. Zastępcą dyrektora początkowo był dr Kazimierz Warchulski, a od września 1988 roku prof. dr hab. Jan Bochenek. Po przejściu profesora Barańskiego na emeryturę w 1985 roku Zakładem Analizy Matematycznej kierowała doc. dr hab. Irena Łojczyk-Królikiewicz.

W Instytucie Matematyki Politechniki Warszawskiej 20 kwietnia 1989 roku uzyskała habilitację dr Teresa Winiarska.

Pierwszego listopada 1990 roku utworzono nowy Zakład Matematyki Stosowanej, którego kierownikiem został dr hab. inż. Leszek Demkowicz, a po kilku miesiącach, w lutym 1991 roku, zakład ten włączono do Ośrodka Elektronicznej Techniki Obliczeniowej PK. ${ }^{18}$

W marcu 1991 roku dr hab. Irena Łojczyk-Królikiewicz, a w kwietniu 1992 roku dr hab. Teresa Winiarska zostały zatrudnione na stanowisku profesora Politechniki Krakowskiej. Po przejściu profesor Łojczyk-Królikiewicz na emeryturę w październiku 1992 kierownictwo Zakładu Analizy Matematycznej, do roku 1997, objęła dr hab. Teresa Winiarska.

Po śmierci profesora Pałasińskiego, od marca 1991 roku do końca kadencji pełniącym obowiązki dyrektora instytutu został profesor Jan Bochenek, a jego zastępcą była wówczas doc. dr hab. Teresa Winiarska. Natomiast pełniącym obowiązki kierownika, a następnie, od lutego 1992 roku, kierownikiem Zakładu Geometrii Wykreślnej mianowano dra inż. Marcina Jonaka. ${ }^{19}$

Od lutego 1992 do 1997 roku prof. zw. dr hab. Jan Bochenek i dr hab. Teresa Winiarska, prof. PK, byli odpowiednio dyrektorem i zastępcą dyrektora IM PK. Po przejściu profesora Bochenka na emeryturę, od 1997 roku do końca sierpnia 2013 roku funkcję dyrektora sprawowała dr hab. Teresa Winiarska, prof. PK, a funkcję wicedyrektorów dr hab. Piotr Jakóbczak, prof. PK, zastępca dyrektora ds. ogólnych (do roku 2003, kiedy

\footnotetext{
17 APK Feliks Barański (teczka osobowa) sygn. 387/121.

18 Masiarz (red.) 1995, s. 48.

19 Tamże.
} 
zlikwidowano to stanowisko) i dr Adam Winiarz (zastępca dyrektora ds. dydaktycznych, 1997-2006). W roku akademickim 2006/2007 zastępcą dyrektora ds. dydaktycznych był dr hab. Zbigniew Hajto, a następnie od roku 2007 do końca sierpnia 2013 roku - dr Leszek Sławik. W październiku 2008 roku utworzono funkcję wicedyrektora ds. badań i rozwoju, którą nieprzerwanie do chwili obecnej wypełnia dr hab. Ludwik Byszewski, prof. PK. Pierwszego września 2013 roku dyrektorem Instytutu Matematyki został dr hab. Włodzimierz Jelonek, a wicedyrektorem ds. dydaktycznych dr Katarzyna Pałasińska.

Po osiągnięciu przez profesora Jana Bochenka wieku emerytalnego kierownictwo Zakładu Równań Różniczkowych i Analizy Funkcjonalnej objęła dr hab. Teresa Winiarska, prof. PK. Kierowała tym zakładem od 1987 roku do 31 sierpnia 2013 roku. Pełniącym obowiązki kierownika Zakładu Analizy Matematycznej od 1 października 1987 do 31 sierpnia 1999 roku został dr Ludwik Byszewski. W roku akademickim 1999/2000 pełniącym obowiązki kierownika Zakładu Analizy Matematycznej był dr Jan Koroński. ${ }^{20}$ Od 1 września 2000 roku funkcję kierownika Zakładu Analizy Matematycznej ponownie powierzono dr. hab. Ludwikowi Byszewskiemu (po rocznym urlopie) i wypełnia ją do chwili obecnej. Dnia 26 kwietnia 2000 roku dr. Ludwikowi Byszewskiemu zatwierdzono habilitację uzyskaną 14 maja 1998 roku w Instytucie Matematyki Politechniki Warszawskiej. Niedługo potem, w dniu 27 października 2000 roku w Instytucie Matematyki Polskiej Akademii Nauk w Warszawie habilitował się dr Włodzimierz Jelonek.

Pierwszego października 2004 roku dr hab. Ludwik Byszewski został mianowany profesorem Politechniki Krakowskiej.

Dnia 4 lutego 2009 roku habilitację z mechaniki na Wydziale Mechanicznym Politechniki Krakowskiej uzyskała dr inż. Anna Kumaniecka, a 31 października 2013 roku habilitację z matematyki na Wydziale Matematyki i Informatyki UJ uzyskał dr Piotr Kot.

Poniżej przedstawimy ramowy opis osiągnięć najwybitniejszych matematyków, którzy zakończyli działalność naukową w ramach zatrudnienia w Politechnice Krakowskiej co najmniej 15 lat temu.

\subsection{Ogólna charakterystyka osiągnięć naukowych prof. Feliksa Barańskiego}

Profesor Feliks Barański do Krakowa przybył po II wojnie światowej ze Lwowa, gdzie ukończył matematykę na Uniwersytecie Jana Kazimierza. Opiekunami jego pracy magisterskiej Zastosowanie teorii operacji do metody sumowalności Toeplitza byli Stefan Banach i Hugo Steinhaus.

W 1944 roku, po opuszczeniu Lwowa przez Niemców, Barański - jako wyjątkowo uzdolniony matematyk - został zatrudniony na stanowisku asystenta u Banacha w Katedrze Mechaniki Teoretycznej Politechniki Lwowskiej, gdzie pracował do 1945 roku.

Zasadniczy wpływ na jego zainteresowania naukowe w Krakowie miał Mirosław Krzyżański, który był światowej sławy specjalistą w zakresie równań różniczkowych cząstkowych.

${ }^{20}$ Materiały archiwalne Instytutu Matematyki Politechniki Krakowskiej, sygn. R-113/4625/99. 

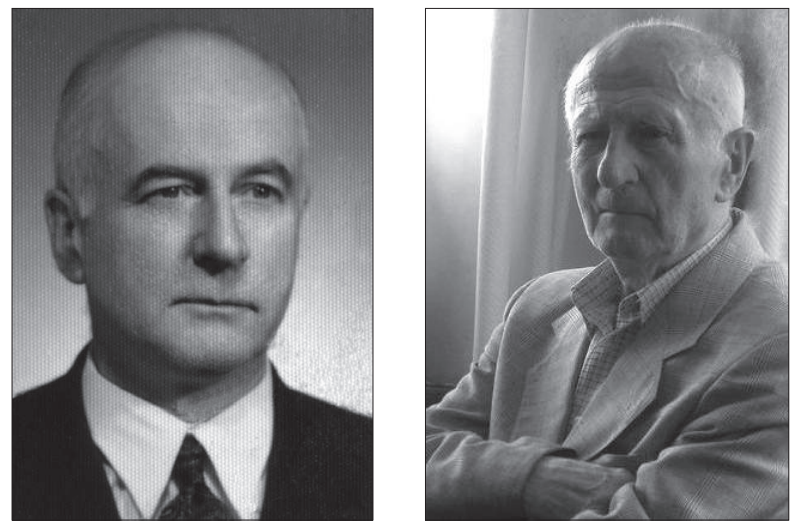

Feliks Barański (1915-2006) $)^{21}$

Profesor Barański kontynuował tematykę profesora Krzyżańskiego. Działalność naukowa Feliksa Barańskiego dotyczyła głównie równań różniczkowych cząstkowych typu eliptycznego i parabolicznego drugiego i wyższych rzędów. Początkowo pracował w obszarze jakościowej teorii równań różniczkowych. Uzyskał w tej dziedzinie kilka istotnych wyników naukowych, wykorzystywanych następnie przez innych matematyków.

$\mathrm{Z}$ czasem jego zainteresowania skoncentrowały się na równaniach liniowych lub quasi-liniowych rzędu drugiego oraz równaniach rzędów wyższych, najczęściej w tak zwanej postaci iterowanej, zarówno w obszarach ograniczonych, jak i nieograniczonych. Metody stosowane $\mathrm{w}$ omawianych pracach to głównie teoria potencjału z wykorzystaniem stosownych konstrukcji funkcji Greena. Barański konstruował funkcje Greena dla różnych równań różniczkowych, obszarów i warunków brzegowych. Ich zastosowanie pozwala na efektywne rozwiązywanie zagadnień granicznych dla równań liniowych w pewnych obszarach lub nieliniowych zagadnień granicznych dla równań różniczkowych poprzez ich sprowadzenie do równań całkowych, które z kolei, przy odpowiednich założeniach, można rozwiązać, stosując na przykład metodę punktu stałego.

Współpraca Barańskiego i Krzyżańskiego zaowocowała wydaniem w 1952 roku wspólnego skryptu Równania liniowe o pochodnych czastkowych drugiego rzędu (Cz. II, Kraków: PWN) poprzedzającego powszechnie znaną dwutomową monografię profesora Krzyżańskiego pt. Równania różniczkowe cząstkowe rzędu drugiego. W pierwszym tomie tej monografii zostały zamieszczone trzy dodatki opracowane przez profesora Feliksa Barańskiego, a we wspomnianym wcześniej skrypcie opracował on na podstawie wykładów i seminarium Krzyżańskiego dwa rozdziały (trzeci i czwarty) o objętości 133 stron. Mówi o tym sam M. Krzyżański w przedmowie do tegoż skryptu i w przedmowie do cz. II monografii.

Dorobek naukowy Feliksa Barańskiego liczy 86 pozycji. Ponadto istnieje kilka monografii naukowych poświęconych równaniom różniczkowym, wydanych pod jego redakcją naukową.

${ }^{21}$ Fotografie $\mathrm{z}$ archiwum rodziny F. Barańskiego. 
Feliks Barański jako nauczyciel był bardzo wysoko oceniany przez uczniów. Nie szczędził im czasu na dyskusje naukowe, a jego dom był zawsze dla nich otwarty. Podczas spotkań naukowych i towarzyskich atmosfera przypominała tę, znaną z opisów, ze spotkań matematyków lwowskich w Kawiarni Szkockiej. Interesował się również sprawami osobistymi swoich uczniów.

Tematykę badawczą prof. Barańskiego najbardziej intensywnie rozwijali dr hab. Ludwik Byszewski, prof. PK i dr Jan Koroński. Uzyskali oni szereg znaczących rezultatów naukowych w zakresie równań różniczkowych cząstkowych rzędów wyższych.

\subsection{Ogólna charakterystyka osiągnięć naukowych} dr hab. Ireny Łojczyk-Królikiewicz, prof. Politechniki Krakowskiej
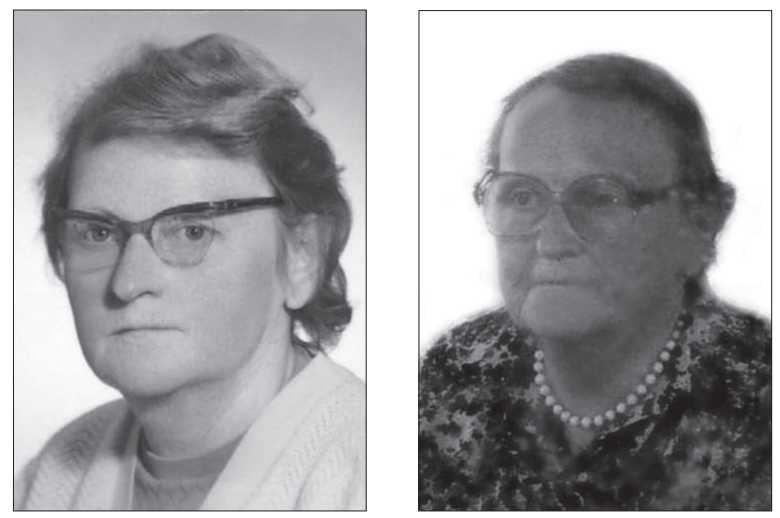

Irena Łojczyk-Królikiewicz (ur. 1922)

Twórczość naukowa prof. Ireny Łojczyk-Królikiewicz dotyczyła początkowo równań różniczkowych typu parabolicznego i powstawała pod kierunkiem jej promotora prof. M. Krzyżańskiego. W późniejszym czasie nawiązała ona również współpracę z prof. Jackiem Szarskim, co wpłynęło na poszerzenie jej zainteresowań naukowych o teorię nierówności różniczkowych w zastosowaniu do układów równań różniczkowo-funkcjonalnych typu eliptycznego i parabolicznego, głównie nieliniowych. W tej dziedzinie uzyskała znaczące wyniki. W rozważanych przez siebie układach równań zaprzestała wykorzystywania warunku quasi-monotoniczności, który jest definiowany i stosowany przez innych autorów. W tym sensie prof. I. Łojczyk-Królikiewicz wypracowała nowe podejście do rozważanych zagadnień naukowych.

Na szczególną uwagę zasługuje wprowadzona przez nią metoda funkcji stosownych (appropriate functions). Nowość tego podejścia polega na zdefiniowaniu klasy tzw. funkcji stosownych, które przy pewnym dodatkowym założeniu („separatywności”) stają się funkcjami górnymi i dolnymi dla rozważanego zagadnienia. Jest to warunek zarówno konieczny, jak i wystarczający na to, by zbiory funkcji dolnych oraz górnych były rozdzielone. Wynika stąd możliwość efektywnej konstrukcji dwóch ciągów monotonicznych jednostajnie zbieżnych, wyznaczających w granicy jednoznaczne rozwiązanie rozważanych 
problemów. W tym kontekście warto zwrócić uwagę na monografię profesor Królikiewicz: A method of appropriate functions to the ordinary second order functional-differential systems (Ed. J. Koroński, Cracow 2015: Cracow University of Technology), dotyczącą układów równań różniczkowych zwyczajnych rzędu drugiego, gdzie w rozdziale III, wprowadzając odpowiednie warunki Lipschitza, są udowodnione twierdzenia o istnieniu rozwiązania rozważanego problemu. Korzystając z definicji całki Kurzweila-Henstocka w rozważanym (ograniczonym lub nieograniczonym) przedziale, konstruuje się dwa ciągi monotoniczne, jednostajnie zbieżne prawie wszędzie w rozważanym przedziale. Wspólna granica tych ciągów jest regularnym rozwiązaniem prawie wszędzie w rozważanym przedziale. Ta własność oznacza, że rozwiązanie jest ciągłe wraz z pierwszą pochodną w rozważanym przedziale, a druga pochodna istnieje tylko prawie wszędzie w tym przedziale. Warunki brzegowe postawione są $\mathrm{w}$ postaci odpowiednich granic w punktach brzegowych rozważanego przedziału. Metoda ta przenosi się na układy eliptyczne i paraboliczne.

Problematyką naukową prof. Łojczyk-Królikiewicz intensywnie zajmowała się jej doktorantka dr Lidia Skóra, uzyskując interesujące i istotne wyniki naukowe.

\subsection{Ogólna charakterystyka osiągnięć naukowych prof. Jana Bochenka}

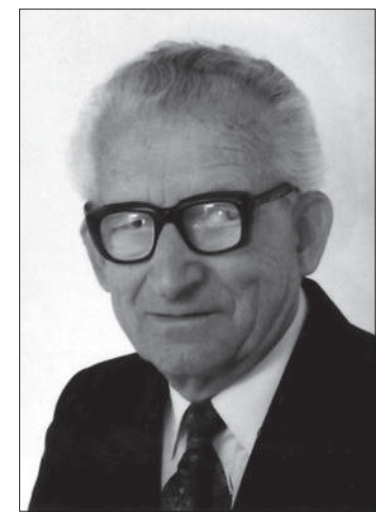

Jan Bochenek (1927-2009)

Działalność naukowa profesora Bochenka ${ }^{22}$ obejmowała wybrane zagadnienia $\mathrm{z}$ teorii równań różniczkowych w przestrzeniach Banacha i spektralnej teorii operatorów. Prace $\mathrm{z}$ teorii równań różniczkowych w przestrzeniach Banacha głównie dotyczyły zagadnień istnienia i jednoznaczności rozwiązań problemu Cauchy’ego dla równań ewolucyjnych rzędu pierwszego i wyższych poprzez zastosowanie teorii półgrup i teorii operatorowej funkcji cosinus.

W zakres tej tematyki wchodzą równania różniczkowe z parametrem. Zajmowała się nimi prof. Teresa Winiarska. Problematykę badawczą profesora Bochenka oprócz niej

${ }^{22}$ Masiarz (red.) 1995, s. 51. 
bardziej aktywnie podjęli: Monika Kozak, Wacław Pielichowski i w pewnym stopniu Lech Sławik oraz Ludwik Byszewski.

W zakresie spektralnej teorii operatorów profesor Bochenek zajmował się zagadnieniami istnienia i własności wartości i funkcji własnych dla operatorów różniczkowych zwyczajnych rzędu drugiego i wyższych rzędów oraz dla operatorów różniczkowych cząstkowych parabolicznych i eliptycznych. Rozważał także tzw. zagadnienia odwrotne typu Sturma-Liouville’a oraz istnienie i własności głównej wartości własnej dla operatorów liniowych i nieliniowych.

\section{Wydział Fizyki Technicznej i Modelowania Komputerowego Politechniki Krakowskiej (obecnie Wydział Fizyki, Matematyki i Informatyki)}

Pierwszego stycznia 1999 roku w politechnice powstał nowy Wydział Fizyki Technicznej i Modelowania Komputerowego. Prace organizacyjne związane z jego powołaniem trwały od roku 1997. Senat Politechniki Krakowskiej w dniu 4 grudnia 1998 roku zadecydował o połączeniu instytutów międzywydziałowych, a mianowicie: Instytutu Fizyki, Instytutu Matematyki, Uczelnianego Centrum Komputerowego oraz Instytutu Ekonomii, Socjologii i Filozofii.

Od początku istnienia nowego wydziału pracownicy Instytutu Matematyki byli reprezentowani w jego władzach. Dr hab. Ludwik Byszewski sprawował funkcję prodziekana ds. studenckich w okresie od 1 lutego do 31 sierpnia 1999 roku i ponownie przez kolejne dwie kadencje od 1 listopada 2002 do 31 sierpnia 2008 roku (od października 2004 roku jako profesor PK). Od 1 września 2008 do 31 sierpnia 2013 roku prodziekanem ds. dydaktycznych był dr hab. Włodzimierz Jelonek, a od 1 września 2013 roku do chwili obecnej jest nim m.in. dr Lech Sławik ${ }^{23}$ (zwykle we władzach WFMiI jest kilku prodziekanów).

Od momentu powstania wydział miał już swoich studentów na kierunku Fizyka Techniczna. Uruchomienie studiów matematycznych stało się możliwe, gdy Senat Politechniki Krakowskiej 10 grudnia 1999 roku uchwalił powstanie w roku akademickim 2000/2001 kierunku studiów Matematyka, trwających 5 lat i dających absolwentom tytuły magistrów matematyki. W grudniu 2001 roku Senat PK postanowił uruchomić od roku akademickiego 2002/2003 międzywydziałowy kierunek studiów Informatyka. Studenci mieli uczyć się na nim 3,5 roku i uzyskać tytuł inżyniera lub 5 lat i zakończyć studia z tytułem magistra inżyniera.

W dniu 22 września 2006 roku została przyjęta uchwała Senatu o zmianie nazwy wydziału na Wydział Fizyki, Matematyki i Informatyki Stosowanej. W roku 2011 kolejny raz ją zmieniono i obecnie jest to Wydział Fizyki, Matematyki i Informatyki. ${ }^{24}$

${ }^{23}$ Materiały archiwalne Instytutu Matematyki Politechniki Krakowskiej, sygn. R-1/003295/2012.

${ }^{24}$ Koroński 2012, s. 22. 
Aktualnie wydział ten prowadzi studia na trzech kierunkach: Matematyki, Fizyki Technicznej i Informatyki. Są one realizowane w formie studiów stacjonarnych i niestacjonarnych w dwustopniowym systemie bolońskim.

Do roku 2015 strukturę Instytutu Matematyki Politechniki Krakowskiej, umiejscowionego w ramach Wydziału Fizyki, Matematyki i Informatyki, stanowiły trzy zakłady: Zakład Analizy Matematycznej pod kierownictwem dra hab. Ludwika Byszewskiego, prof. PK, Zakład Równań Różniczkowych i Analizy Funkcjonalnej z prof. dr hab. Anatolijem Plichko, który kierował nim od 1 września 2013 roku i Zakład Metod Geometrycznych pod kierownictwem dra hab. Włodzimierza Jelonka (od 01.03.2002). Wcześniej (01.10.1996 -31.08.2013) istniał jeszcze czwarty zakład - Analizy Zespolonej, którym kierował doc. dr hab. Piotr Jakóbczak, zatrudniony poprzednio na stanowisku profesora PK. Po reorganizacji Instytutu Matematyki PK zlikwidowano go z dniem 1 września 2013 roku.

W dniu 16 grudnia 2015 roku Rada Wydziału Fizyki, Matematyki i Informatyki zmieniła strukturę Instytutu Matematyki PK, powołując z dniem 1 stycznia 2016 roku następujące zakłady: Zakład Analizy Matematycznej (kierownik - dr hab. Ludwik Byszewski, prof. PK), Zakład Metod Geometrycznych i Analizy Zespolonej (kierownik dr hab. Włodzimierz Jelonek), Zakład Równań Różniczkowych i Analizy Funkcjonalnej (kierownik - prof. dr hab. Anatolij Plichko), Zakład Algebry (kierownik - prof. dr hab. Orest Artemovych), Zakład Metod Statystycznych (kierownik - dr hab. inż. Jacek Leśkow, prof. PK) $)^{25}$.

Zwięzłą charakterystykę badań naukowych aktualnie prowadzonych przez pracowników naukowo-dydaktycznych Instytutu Matematyki Politechniki Krakowskiej przytoczymy z jego strony:

Podstawową dziedziną badań naukowych Instytutu Matematyki są równania różniczkowe. Prace badawcze dotyczą głównie następujących zagadnień: równań różniczkowych w abstrakcyjnych przestrzeniach, równań ewolucyjnych, równań z parametrem, równań i nierówności różniczkowo-funkcjonalnych, nielokalnych zagadnień granicznych, spektralnej teorii operatorów różniczkowych oraz klasycznych zagadnień granicznych dla równań różniczkowych fizyki matematycznej. Ponadto w Instytucie rozwijane są również wybrane działy geometrii różniczkowej, analizy zespolonej, geometrii algebraicznej, rachunku prawdopodobieństwa, procesów stochastycznych, logiki, teorii mnogości i topologii, zastosowań matematyki w technice. Instytut współpracuje naukowo głównie z Instytutem Matematyki Uniwersytetu Jagiellońskiego oraz z Wydziałem Matematyki Stosowanej AGH i Wydziałem Matematyki i Nauk Informacyjnych Politechniki Warszawskiej. ${ }^{26}$

${ }^{25}$ Materiały archiwalne Instytutu Matematyki Politechniki Krakowskiej - Protokół z posiedzenia nr 104 Rady Wydziału Fizyki, Matematyki i Informatyki w dniu 16.12.2015.

${ }^{26}$ Instytut Matematyki Wydziału Fizyki, Matematyki i Informatyki Politechniki Krakowskiej 2015. 
Instytut Matematyki Politechniki Krakowskiej wypromował dotychczas kilkuset magistrów matematyki i kilkudziesięciu licencjatów matematyki w wyżej wymienionych specjalnościach.

Instytut prowadzi zajęcia z matematyki prawie na wszystkich wydziałach i kierunkach studiów w Politechnice Krakowskiej za wyjątkiem Wydziału Architektury, gdzie bardzo skromny program tego przedmiotu realizują pracownicy Zakładu Geometrii Wykreślnej i Grafiki Inżynierskiej. (Do początkowych lat 90. matematycy z Instytutu Matematyki PK prowadzili zajęcia na Wydziale Architektury w szerokim zakresie.) Instytut Matematyki wykonuje olbrzymią pracę dydaktyczną na rzecz całej uczelni. Praca ta jest tym trudniejsza, im słabsze przygotowanie słuchaczy do studiów. Z roku na rok absolwenci szkół średnich - po kolejnych pseudo-reformach nauczania matematyki w szkołach podstawowych, gimnazjach i szkołach średnich oraz przy systematycznym zmniejszaniu liczby godzin przeznaczonych na matematykę na każdym poziomie nauczania tego przedmiotu dysponują coraz skromniejszym zasobem wiedzy i umiejętności.

Aktualnie w Instytucie Matematyki jest zatrudnionych ponad 40 nauczycieli akademickich na różnych stanowiskach naukowo-dydaktycznych i dydaktycznych.

Łącznie w ciągu siedemdziesięciu lat działalności Politechniki Krakowskiej liczbę zatrudnionych w tej uczelni matematyków można szacować na około dwieście osób, wśród których nierzadko są matematycy o poważnym wkładzie w rozwój uprawianych przez siebie dziedzin naukowych.

\section{BIBLIOGRAFIA}

\section{ZBIORY ARCHIWALNE}

Archiwum Politechniki Krakowskiej

Mirosław Krzyżański (teczka osobowa), sygn. 98/388.

Feliks Barański (teczka osobowa), sygn. 98/387/121.

Archiwum Uniwersytetu Jagiellońskiego

Krzyżański Mirosław (teczka osobowa), sygn. S III 246.

Krzyżański Mirosław (teczka habilitacyjna), sygn. WMP 46.

Krzyżański Mirosław (teczka profesorska), sygn. MFC 34.

OPRACOWANIA

FLAGA Kazimierz

(red.) 2005: Politechnika Krakowska w latach 1995-2005: Jubileusz 60-lecia Politechniki Krakowskiej im. Tadeusza Kościuszki. Kraków: Wydawnictwo Politechniki Krakowskiej.

INSTYTUT MATEMATYCZNY POLSKIEJ AKADEMII NAUK

2015: Historia. Publikacja dostępna w Internecie: https://www.impan.pl/pl/instytut/historia. 
INSTYTUT MATEMATYKI WYDZIAŁU FIZYKI, MATEMATYKI I INFORMATYKI POLITECHNIKI KRAKOWSKIEJ

2015: Projekty badawcze. Publikacja dostępna w Internecie: http://www.matematyka. pk.edu.pl/?addr=wspolpraca.php.

KOROŃSKI Jan

2012: Królowa nauk dla przyszłych inżynierów. Nasza Politechnika 7-8/2012, ss. 21-22.

2013: Mirosław Krzyżański (1907-1965) i jego monografia z równań różniczkowych cząstkowych. Kwartalnik Historii Nauki i Techniki 58(4), ss. 7-28.

ŁOJCZYK-KRÓLIKIEWICZ Irena

2015: A method of appropriate functions to the ordinary second order functional-differential systems. (Ed. J. Koroński). Kraków: Wydawnictwo Politechniki Krakowskiej. ISBN 978-83-72742-847-9.

\section{MATERIAŁY ARCHIWALNE INSTYTUTU MATEMATYKI}

POLITECHNIKI KRAKOWSKIEJ

Pismo rektora PK z dnia 02.11.1999, sygn. R-113/4625/99.

Pismo rektora PK z dnia 21.08.2012, sygn. R-1/003295/2012.

Protokół z posiedzenia nr 104 Rady Wydziału Fizyki, Matematyki i Informatyki w dniu 16.12.2015 (brak sygnatury).

MASIARZ Władysław

(red.) 1995: Jednostki międzywydziałowe Politechniki Krakowskiej. Kraków: Wydawnictwo Politechniki Krakowskiej.

MUSZYŃSKI Władysław

(red.) 1995: Politechnika Krakowska im. Tadeusza Kościuszki 1945-1995. Kraków: Wydawnictwo Politechniki Krakowskiej.

RĄCZKA Jan Władysław

1976: Politechnika Krakowska 1946-1976. Kraków: Wydawnictwo Politechniki Krakowskiej.

WĄTORSKI Jan

(red.) 1970: Politechnika Krakowska: 1945-1970. Kraków: Wydawnictwo Artystyczno-Graficzne. 


\title{
THE HISTORY OF MATHEMATICS IN THE KRAKOW UNIVERSITY OF TECHNOLOGY (1945-2015)
}

\begin{abstract}
The subject of the paper is the history of Mathematics at the Krakow University of Technology since 1945 up to 2015. It presents profiles of the most famous mathematicians in the history of the Krakow University of Technology (M. Krzyżański, J. Bochenek, F. Barański, I. Łojczyk-Królikiewicz) and some information about their scientific achievements.
\end{abstract}

Keywords: Krakow University of Technology, Institute of Mathematics, History of Mathematics 